\title{
Excess Mortality in Russia in 1868-1912 and Its Historiographic Implications
}

\author{
Sergei Nefedov \\ Institute of History and Archeology Ural Branch of the \\ Russian Academy of Sciences, Yekaterinburg; Ural Feder- \\ al University, Yekaterinburg
}

\section{Michael Ellman}

Emeritus Professor University of Amsterdam

\begin{abstract}
In late imperial Russia, peasants were placed in an extremely difficult situation. The terms of the 1861 Emancipation had left them short of land and highly indebted to the government. Their rate of population growth was extremely high, and as Russia entered the demographic transition, it increased even more. The government was intent on a policy of rapid industrialization, which was ultimately to be paid for by large grain exports. This already strained situation was further complicated by three additional factors. Both the changing level of international grain prices and the weather-induced fluctuations in grain yields were external factors capable of applying severe shocks to the peasantry, and little could be done to affect their impact. The third factor was the effectiveness of the tsarist administrative machinery for levying taxes on the peasants and providing them with relief (Wheatcroft 1991: 128).
\end{abstract}

Keywords: excess mortality, famine, epidemics, food consumption.

\section{INTRODUCTION}

In the present paper by excess mortality we mean the number of deaths under extreme conditions (famine, epidemics, and wars) that exceeds the average in normal years. There is not yet a systematic study of excess mortality in Russia for the period between 1868 and 1913, although there are estimates by Urlanis (1963: 83) and Robbins

Social Evolution \& History, Vol. 20 No. 1, March 2021 173-197

(C) 2021 'Uchitel' Publishing House

DOI: $10.30884 / \mathrm{seh} / 2021.01 .07$ 
(1975: 189) and an overview by Wheatcroft (1992: 53-59) for the famine of 1892 . However, as will be shown in this paper, these estimates are inadequate. As a result, the impact of famine and epidemics in Russia in this period is unclear, which influences general accounts of living standards then. Consequently, determining periods of excess mortality from starvation and epidemics, relating them to their causes, and establishing their geographic range, is important for understanding developments in the period between Emancipation of the serfs and the First World War and the background to events in the first decades of Bolshevik rule.

Some writers distinguish between excess mortality caused by famines and excess mortality caused by epidemics. However, such a distinction is problematic. Starvation leads to a weakening of the immune system and facilitates the spread of infections, as well as the worsening of chronic non-infectious illness, as Shverin (1901: 254-263) long ago pointed out. Therefore, starvation is normally accompanied by the spread of epidemics. Although some authors try to distinguish between starvation and epidemic mortality, in reality that is only possible in those rare cases when the epidemic occurred in a year with a good harvest and was not accompanied by starvation. If the starving die from typhus or cholera it is not possible to distinguish between the victims of starvation and those of epidemics. This is particularly the case in Russia in the period considered, since the registration of causes of death never mentioned starvation but (in the case of epidemics) it was obligatory to mention which disease had caused the death. Alexander S. Pankratov (1913: 175-176) wrote about starvation in 1911-12

Of course, we do not have deaths from starvation as in India: there in times of starvation wasted and emaciated people sit in the street and await death ... We don't have such a frightening starvation. But we do have deaths from starvation. Only they are perceived differently, hardly noticed, not staring one in the face ... Some microbe or other will fly to a famished organism - in rural areas there are swarms of them and the person will die ... The disease is named, but no-one mentions starvation. Nevertheless, it is obvious that the primary cause of death is the lack of food, in other words starvation.

In their detailed discussion of how starvation and disease interact, Mokyr and Ó Grada (2002) explain how starvation can cause disease. They argue that in the Irish famine of the late 1840s most of the excess deaths were caused by disease and not directly by starvation, but that 
these diseases were themselves the result of poor nutrition or the indirect effects of the famine on personal behaviour and social structure. The link between nutrition, morbidity and mortality was also shown by Baten and Wagner (2002) in their analysis of the early Nazi period in Germany. These facts mean that trying to reduce estimates of famine deaths by deducting victims of disease, in general makes no sense.

Cholera is not directly caused by hunger. It is directly caused by a bacterium. However, hunger weakens the body's resistance against the bacterium, and hence makes infection, and in many cases death, more likely. The combination of the bacterium and hunger can be fatal. The interaction between nutrition and disease (it goes in both directions) is a commonplace of the modern medical literature. See for example the symposium on 'Nutrition and infection, Prologue and Progress since 1968' published as a special issue of The Journal of Nutrition vol. 133 issue 1, January 2003. Similarly, Prentice et al. (2008: 1322 and 1324) pointed out that 'malnutrition and infections act hand in hand to create a self-reinforcing downward cycle of tissue depletion and lowered resistance to disease ... Undernourished children are profoundly more likely to die from a wide range of infections than their better nourished counterparts.' Ignoring the contribution of malnutrition to what were reported as cholera deaths goes against the evidence.

\section{ESTIMATING EXCESS MORTALITY IN 1889-1893}

In this paper, the estimates of excess mortality are based on the annual mortality figures for 50 provinces (guberniia) of the European part of the Russian Empire, which are available in the publications of the Central Statistical Committee of the Ministry of Internal Affairs (Статистический временник Российской империи [Statistical bulletin of the Russian Empire], Статистика Российской империи [Statistics of the Russian Empire], Статистический ежегодник Poccuи [Statistical Yearbook of Russia], Сборник сведений по Pосcuи за 1884-1885 [Collection of information on Russia for 18841885]). These publications contain statistics for the period from 1867 to 1913 which enable the calculation of excess mortality between 1868 and 1912.

Data on mortality in the period considered was obtained by the statistical organizations primarily from local priests who conducted funerals. This method of mortality registration naturally led to some underestimation because it does not include those adults who were buried without funerals and children who died before baptism. However, in normal years this underestimate was unimportant. Nevertheless, in years with a 
major famine, like in 1892, people searching for food often tried to reach towns and frequently died on the way, so that the mortality underestimate increased. The result is that the estimates of excess mortality using the currently available data are underestimates.

To proceed, it is necessary to determine the crisis years that resulted in excess deaths. Figure 1 shows the fluctuations in the mortality rate in the period considered, drawing attention to peak mortality years and, in cases where there were two adjacent years with high mortality, to both years (e.g., 1882-1883). The crises of 1882-83 and 1901-1902 were such two-year crises and the crisis whose peak was the 'great famine' (in Russian tsar' golod literally 'tsar famine') of 1892 lasted for five years (1889-1893).

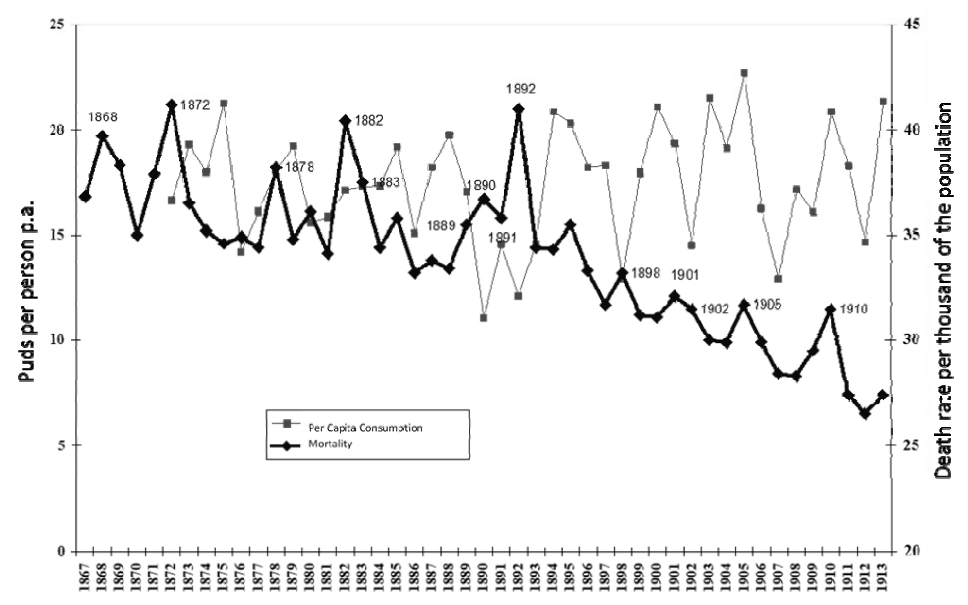

Fig. 1. Mortality and food consumption 1867-1913

Source: Rashin (1956: 155-156), Nefedov (2005: 259). These passages are based on the contemporary official statistics mentioned in the text.

Notes: (a) One pood equals 16.38 kilograms.

(b) The food consumption figures show the amount of grain consumed by people and livestock, after deducting seed and exports from production, but not deducting the grain used for the production of vodka or by the army. However, they exaggerate grain consumption since the official production figures from which they are derived measure co-called biological yield rather than barn yield (Ostrovsky 2013: 201).

(c) The contemporary data are based on the data for agricultural years (which for contemporary official statistics ran from September 1 of one year to August 31 of the following year). Hence the consumption in a calendar year $x$ depends on the harvest in calendar year $x-1$. Also, the number shown for consumption in year $x$ is actually the harvest of year $x-1$ (subject to note $\mathrm{b}$ ) assumed to be consumed in the period September 1 of year $x-1$ to August 31 in year $x$. 
Although the absolute consumption levels shown in Figure 1, as estimates of human consumption, have a margin of error (for the reasons mentioned in note b), Figure 1 does show the volatility of food consumption in this period and the close relationship between bad harvests and leaps in mortality.

For the measurement of excess mortality in the crisis years various methods are possible. Boris Urlanis and Stephen G. Wheatcroft calculated the difference between the number of those who died in 1892 and the average number of deaths in the four closest years $(1890,1891$, 1893, and 1894). Richard G. Robbins (1975: 237) used the average for five years $(1888,1889,1890,1893$, and 1894) but noted that in 1893 there was still a high mortality level, and for that year he excluded several provinces from his calculations. It seems probable that this was the reason why 1891 was excluded from his calculations. The crisis lasted for five years reaching its height in 1892 . The increase in mortality began already in 1889 . Therefore, estimating excess mortality in 1892 by comparing mortality in 1892 with that in years when mortality was already unusually high, as is done by Urlanis and Wheatcroft gives an underestimate of the excess mortality. Robbins tried to deal with this problem by ignoring the year before 1892, but this was insufficient because he also used for comparison with 1892 the years 1890 and 1889 which were also years of increased mortality. In order to calculate the true extent of excess mortality during this crisis, it is necessary to consider not just excess mortality in 1892 but also that in adjacent years.

For the purpose of calculating excess mortality $\Delta \mathrm{S}$, it is necessary to compare mortality $\mathrm{S}_{0}$ for the five years $1889-1893$ with abovenormal mortality, with the number of deaths $S_{1}$ in the previous five years (1884-1888) and the number of deaths $S_{2}$ in the following five years (1894-1898). Since the total population was growing exponentially, geometric means are more relevant than arithmetic ones. That means that the excess mortality for the five-year period from 1889 to 1893 should be calculated as

$$
\Delta \mathrm{S}=\mathrm{S}_{0}-\sqrt{ }\left(\mathrm{S}_{1} \times \mathrm{S}_{2}\right)
$$

Analogously, for the crises lasting for two years, the comparison should be with the preceding and subsequent two-year periods, and for crises lasting for just one year, with the previous and following years. Since the situation in various provinces differed enormously, to get a clear picture of what happened it is necessary to calculate the excess deaths in each province separately. For each province the estimates for excess mortality were calculated as indicated above, i.e. by comparing the crisis year/s with an appropriate number of normal years using geometric averages. The results are presented in Table 1. 
Table 1

Estimated excess mortality in $\mathbf{5 0}$ provinces of European Russia (thousands)

\begin{tabular}{|c|c|c|c|c|c|c|c|c|c|c|c|c|}
\hline 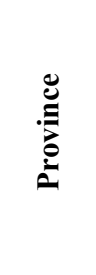 & $\begin{array}{l}\infty \\
\infty \\
\infty\end{array}$ & $\underset{\infty}{N}$ & $\stackrel{\infty}{\infty}$ & $\begin{array}{l}\infty \\
\infty \\
\infty \\
\stackrel{1}{1} \\
\infty \\
\infty\end{array}$ & 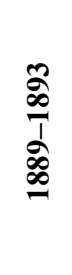 & $\stackrel{\infty}{\infty}$ & $\frac{\text { 용 }}{\frac{1}{8}}$ & ڤ̊ & 음 & $\stackrel{\bar{\pi}}{0}$ & 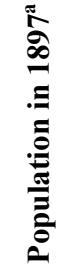 & 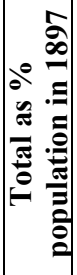 \\
\hline $\begin{array}{l}\text { Ar- } \\
\text { khan- } \\
\text { gelsk }\end{array}$ & 1.1 & 0.0 & 1.4 & 0.0 & 3.9 & 0.0 & 3.8 & 0.0 & 0.0 & 10.1 & 347 & 2.9 \\
\hline $\begin{array}{l}\text { Astra- } \\
\text { khan }\end{array}$ & 0.0 & 1.2 & 1.5 & 10.2 & 31.1 & 0.5 & 0.9 & 2.6 & 1.2 & 49.2 & 1004 & 4.9 \\
\hline $\begin{array}{l}\text { Bessa- } \\
\text { rabia }\end{array}$ & 0.0 & 9.7 & 7.4 & 6.2 & 31.5 & 0.0 & 0.0 & 6.8 & 6.4 & 68.0 & 1935 & 3.5 \\
\hline $\begin{array}{l}\text { Cher- } \\
\text { nigov }\end{array}$ & 5.3 & 26.8 & 1.0 & 17,3 & 20.1 & 0.0 & 0.0 & 4.4 & 11.0 & 85.9 & 2298 & 3.7 \\
\hline $\begin{array}{l}\text { Cour- } \\
\text { land }\end{array}$ & 0.0 & 0.0 & 0.7 & 1.2 & 2.9 & 0.0 & 0.0 & 4.1 & 0.5 & 9.4 & 674 & 1.4 \\
\hline $\begin{array}{l}\text { Don } \\
\text { Host }\end{array}$ & 0.0 & 3.1 & 2.4 & 24.9 & 72.4 & 2.7 & 18.7 & 14.1 & 35.9 & 174.2 & 2564 & 6.8 \\
\hline $\begin{array}{l}\text { Ekate- } \\
\text { rino- } \\
\text { slav }\end{array}$ & 0.7 & 17.2 & 6.1 & 15.6 & 23.8 & 0.2 & 11.5 & 19.8 & 22.6 & 117.5 & 2114 & 5.6 \\
\hline $\begin{array}{l}\text { Esto- } \\
\text { nia }\end{array}$ & 1.2 & 1.8 & 0.6 & 0.7 & 0.0 & 0.0 & 0.0 & 1.1 & 0.0 & 5.5 & 413 & 1.3 \\
\hline $\begin{array}{l}\text { Grod- } \\
\text { no }\end{array}$ & 1.9 & 3.1 & 3.3 & 0.0 & 0.9 & 0.0 & 0.0 & 4.6 & 3.2 & 17.0 & 1603 & 1,1 \\
\hline $\begin{array}{l}\text { Kalu- } \\
\text { ga }\end{array}$ & 3.2 & 0.0 & 5.8 & 2.5 & 10.9 & 0.0 & 6.6 & 5.3 & 6.9 & 41.3 & 1133 & 3.6 \\
\hline $\begin{array}{l}\text { Kau- } \\
\text { nas }\end{array}$ & 5.7 & 1.7 & 1.5 & 3.6 & 18.3 & 0.0 & 7.4 & 5.8 & 3.2 & 47.4 & 1545 & 3.1 \\
\hline Kazan & 0.0 & 2.3 & 13.4 & 15.0 & 61.4 & 9.0 & 7.5 & 0.0 & 6.5 & 115.0 & 2171 & 5.3 \\
\hline $\begin{array}{l}\text { Khar- } \\
\text { kiv }\end{array}$ & 0.0 & 28.7 & 7.7 & 37.7 & 50.2 & 4.8 & 5.2 & 5.0 & 13.9 & 153.4 & 2492 & 6.2 \\
\hline $\begin{array}{l}\text { Kher- } \\
\text { son }\end{array}$ & 6.0 & 13.4 & 4.5 & 15.1 & 5.1 & 3.2 & 0.0 & 0.0 & 21.8 & 69.1 & 2734 & 2.5 \\
\hline $\begin{array}{l}\text { Ko- } \\
\text { stroma }\end{array}$ & 1.6 & 0.3 & 0.0 & 0.0 & 6.3 & 11.7 & 18.0 & 5.0 & 8.4 & 51.3 & 1387 & 3.7 \\
\hline Kursk & 6.0 & 1.1 & 3.0 & 28.5 & 40.2 & 1.7 & 0.4 & 7.3 & 0.0 & 88.2 & 2371 & 3.7 \\
\hline Kyiv & 9.8 & 40.6 & 10.7 & 33.5 & 52.5 & 0.0 & 0.0 & 5.0 & 24.2 & 176.3 & 3559 & 5.0 \\
\hline
\end{tabular}


Table 1 (continued)

\begin{tabular}{|c|c|c|c|c|c|c|c|c|c|c|c|c|}
\hline 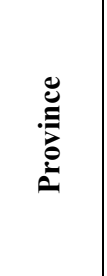 & $\begin{array}{l}\infty \\
\infty \\
\infty\end{array}$ & $\underset{\infty}{\mathbb{\infty}}$ & $\stackrel{\infty}{\infty}$ & $\begin{array}{l}\infty \\
\infty \\
\infty \\
\tilde{D} \\
\infty \\
\infty \\
\infty\end{array}$ & $\begin{array}{l}\stackrel{\infty}{\frac{1}{1}} \\
\stackrel{\infty}{\varrho}\end{array}$ & $\stackrel{\infty}{\infty}$ & 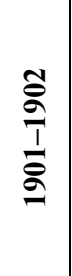 & ఏิ & $\frac{0}{2}$ & हैं & 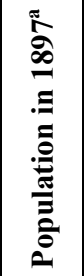 & 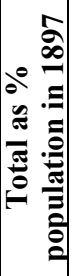 \\
\hline $\begin{array}{l}\text { Livo- } \\
\text { nia }\end{array}$ & 4.7 & 0.8 & 4.1 & 0.0 & 1.2 & 0.0 & 1.2 & 3.8 & 0.4 & 16.3 & 1299 & 1,3 \\
\hline Minsk & 3.9 & \begin{tabular}{|l|}
7.9 \\
\end{tabular} & 0.5 & \begin{tabular}{|l|}
0.0 \\
\end{tabular} & 0.0 & \begin{tabular}{|l|}
0.0 \\
\end{tabular} & 3.1 & 3.2 & 5.6 & 24.3 & 2148 & 1,1 \\
\hline $\begin{array}{l}\text { Mogi- } \\
\text { lev }\end{array}$ & 9.6 & 12.7 & 2.5 & 0.0 & 7.4 & 0.0 & 6.6 & 3.8 & 5.0 & 47.6 & 1687 & 2,8 \\
\hline $\begin{array}{l}\text { Mos- } \\
\text { cow }\end{array}$ & 14.7 & 0.0 & 5.2 & 11.3 & 8.9 & 3.3 & 5.1 & 6.2 & 0.0 & 54.7 & 2431 & 2,2 \\
\hline $\begin{array}{l}\text { Nizhny } \\
\text { Novgo- } \\
\text { rod }\end{array}$ & 0.0 & 1.4 & 9.5 & 15.1 & 26.0 & 8.0 & 4.3 & 3.9 & 0.3 & 68.6 & 1585 & 4.3 \\
\hline $\begin{array}{l}\text { Nov- } \\
\text { gorod }\end{array}$ & 8.0 & 0.0 & 1,1 & 2.7 & 0.0 & 3.4 & 4.0 & 6.1 & 3.3 & 28.6 & 1367 & 2.1 \\
\hline $\begin{array}{l}\text { Olo- } \\
\text { nets }\end{array}$ & 2.3 & 1.4 & 2.6 & 0.0 & 3.6 & 0.8 & 1.1 & 0.0 & 1.4 & 13.1 & 364 & 3.6 \\
\hline $\begin{array}{l}\text { Oren- } \\
\text { burg }\end{array}$ & 5.3 & 1,0 & 0.0 & 27.8 & 36.8 & 0.0 & 0.0 & 0.0 & 4.4 & 75.2 & 1600 & 4.7 \\
\hline Orlov & 0.3 & \begin{tabular}{|l|}
4.6 \\
\end{tabular} & 3.0 & \begin{tabular}{|l|}
18.7 \\
\end{tabular} & 35.8 & \begin{tabular}{|l|}
7.3 \\
\end{tabular} & 9.8 & \begin{tabular}{|l|}
9.4 \\
\end{tabular} & \begin{tabular}{|l|}
0.3 \\
\end{tabular} & \begin{tabular}{|l|}
89.1 \\
\end{tabular} & 2034 & 4.4 \\
\hline Penza & 0.0 & \begin{tabular}{|l|}
0.0 \\
\end{tabular} & 17.0 & 24.4 & 55.5 & 10.0 & 10.2 & 7.0 & 1.8 & 125.8 & 1470 & \begin{tabular}{|l|}
8.6 \\
\end{tabular} \\
\hline Perm & 7.8 & \begin{tabular}{|l|}
0.0 \\
\end{tabular} & 4.1 & 19,6 & 5.5 & 14.1 & 35.1 & 0.0 & \begin{tabular}{|l|}
0.0 \\
\end{tabular} & \begin{tabular}{|l|}
86.3 \\
\end{tabular} & 2994 & \begin{tabular}{|l|}
2.9 \\
\end{tabular} \\
\hline $\begin{array}{l}\text { Podo- } \\
\text { lia }\end{array}$ & 2.0 & 24.9 & 8.0 & 22.1 & 43.2 & 0.0 & 0.0 & 22.6 & 21.2 & 143.9 & 3018 & 4.8 \\
\hline $\begin{array}{l}\text { Polta- } \\
\text { va }\end{array}$ & 8.4 & 44.3 & 8.5 & 24.1 & 36.7 & 0.0 & 2.0 & 7.3 & 5.9 & 137.1 & 2778 & 4.9 \\
\hline Pskov & 9.2 & 2.6 & 0.9 & 0.0 & 0.0 & 0.0 & 2.9 & 2.6 & 1.5 & \begin{tabular}{|l|}
19.7 \\
\end{tabular} & 1122 & \begin{tabular}{|l|}
1.8 \\
\end{tabular} \\
\hline $\begin{array}{l}\text { Rya- } \\
\text { zan }\end{array}$ & 0.3 & 0.9 & 8.0 & 8.6 & 29.7 & 10.7 & 12.1 & 6.2 & 4.8 & 81.2 & 1802 & 4.5 \\
\hline $\begin{array}{l}\text { St. } \\
\text { Peters- } \\
\text { burg } \\
\end{array}$ & 7.1 & 6.1 & 8.8 & 1.6 & 0.0 & 2.2 & 0.6 & 3.3 & 7.9 & 37.6 & 2112 & 1.8 \\
\hline $\begin{array}{l}\text { Sama- } \\
\text { ra }\end{array}$ & 0.0 & 3.5 & 22.1 & 40.8 & 107.3 & 11.5 & 5.5 & 0.0 & 25.4 & 216.1 & 2751 & 7.9 \\
\hline $\begin{array}{l}\text { Sara- } \\
\text { tov }\end{array}$ & 11.2 & 0.0 & 23.4 & 31.5 & 81.4 & 11.9 & 8.3 & 5.6 & 11.0 & 184.3 & 2406 & 7.7 \\
\hline $\begin{array}{l}\text { Sim- } \\
\text { birsk }\end{array}$ & 0.0 & 0.5 & 13.3 & 25.5 & 51.9 & 7.6 & 6.0 & 3.7 & 12.0 & 120.5 & 1528 & 7.9 \\
\hline
\end{tabular}


Table 1 (continued)

\begin{tabular}{|c|c|c|c|c|c|c|c|c|c|c|c|c|}
\hline 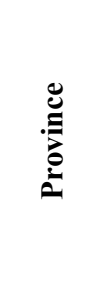 & $\begin{array}{l}\infty \\
\infty \\
\infty\end{array}$ & $\underset{\infty}{\mathbb{\infty}}$ & $\underset{\infty}{\infty}$ & $\begin{array}{l}\infty \\
\infty \\
\stackrel{D}{1} \\
\tilde{\infty} \\
\infty \\
\infty\end{array}$ & $\begin{array}{l}\stackrel{\infty}{\frac{1}{1}} \\
\infty \\
\infty\end{array}$ & $\stackrel{\infty}{\infty}$ & 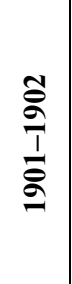 & $\mathscr{\varrho}$ & 음 & हैं & 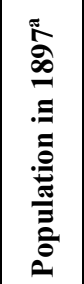 & 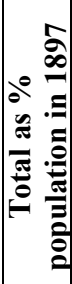 \\
\hline $\begin{array}{l}\text { Smo- } \\
\text { lensk }\end{array}$ & 20.1 & 0.0 & 4.3 & 0.0 & 3.3 & 0.0 & 15.6 & 7.9 & 12.0 & 63.0 & 1525 & 4.1 \\
\hline $\begin{array}{l}\text { Tam- } \\
\text { bov }\end{array}$ & 0.0 & 0.0 & 19.1 & 22.6 & 83.2 & 21.7 & 35.0 & 7.8 & 0.0 & 189.4 & 2684 & 7.1 \\
\hline $\begin{array}{l}\text { Tau- } \\
\text { rida }\end{array}$ & 1.2 & 0.0 & 1.6 & 4.8 & 12.3 & 3.3 & 1.9 & 0.4 & 4.9 & 30.5 & 1448 & 2.1 \\
\hline Tula & 0.1 & 0.0 & 3.7 & 11.2 & 38.6 & 3.6 & \begin{tabular}{|l|}
0.0 \\
\end{tabular} & \begin{tabular}{|l|}
10.7 \\
\end{tabular} & 6.8 & \begin{tabular}{|l|}
74.7 \\
\end{tabular} & 1419 & 5.3 \\
\hline Tver & 14.0 & 9.6 & 3.8 & 0.0 & 0.0 & 5.0 & 14.5 & 5.0 & \begin{tabular}{|l|}
7.7 \\
\end{tabular} & 59.6 & 1769 & 3.4 \\
\hline Ufa & 0.0 & 0.3 & 3.7 & 23.9 & 58.4 & 3.8 & 0.0 & \begin{tabular}{|l|}
0.0 \\
\end{tabular} & 0.0 & 90.1 & 2197 & 4.1 \\
\hline Vilna & 2.5 & 0.0 & 0.6 & 0.0 & 2.2 & 1.1 & 0.2 & 2.6 & 1.5 & \begin{tabular}{|l|}
10.8 \\
\end{tabular} & 1591 & \begin{tabular}{|l|}
0.7 \\
\end{tabular} \\
\hline $\begin{array}{l}\text { Vi- } \\
\text { tebsk }\end{array}$ & 8.5 & 0.0 & 2.0 & 4.2 & 8.3 & 0.0 & 4.0 & 3.9 & 2.0 & 33.0 & 1489 & 2.2 \\
\hline $\begin{array}{l}\text { Vla- } \\
\text { dimir }\end{array}$ & 0.0 & 0.0 & 2.1 & 9.6 & 6.5 & 5.0 & 12.6 & 5.9 & 2.4 & 44.2 & 1516 & 2.9 \\
\hline $\begin{array}{l}\text { Volhy- } \\
\text { nia }\end{array}$ & 3.9 & 20.9 & 6.5 & 14.9 & 0.0 & 0.0 & 0.0 & 9.3 & 11.5 & 67.0 & 2989 & 2.2 \\
\hline $\begin{array}{l}\text { Vo- } \\
\text { logda }\end{array}$ & 4.1 & 0.0 & 1.2 & 0.0 & 6.5 & 6.8 & 21.9 & 1.0 & 1.4 & 43.0 & 1342 & 3.2 \\
\hline $\begin{array}{l}\text { Voro- } \\
\text { nezh }\end{array}$ & 0.0 & 13.9 & 2.3 & 44.3 & 100.6 & 10.8 & 21.5 & 13.7 & 18.1 & 225.2 & 2531 & 8.9 \\
\hline $\begin{array}{l}\text { Vyat- } \\
\text { ka }\end{array}$ & 3.3 & 4.2 & 7.9 & 8.6 & 47.2 & 23.8 & 26.4 & 0.0 & 12.7 & 134.0 & 3031 & 4.4 \\
\hline $\begin{array}{l}\text { Yaro- } \\
\text { slavl }\end{array}$ & 5.6 & 0.0 & 2.2 & 0.0 & 0.0 & 5.7 & 14.6 & 0.5 & 3.7 & 32.3 & 1071 & 3.0 \\
\hline $\begin{array}{l}\text { TO- } \\
\text { TAL }\end{array}$ & 200.7 & & 274.7 & 629.7 & 1 & 5. & 366 & 254. & 362.8 & 3945.5 & 93443 & 4.2 \\
\hline
\end{tabular}

Note: a) 1897 was the year of the first and only census in Tsarist Russia.

Source: The population and mortality data are taken from contemporary official statistics, Statistics of the Russian Empire (1890-1909); Report on the state of public health and the organization of medical care in Russia for 1892 (1896: 33134). The calculation of excess mortality uses this data and the method explained in the text. The Excel file containing the calculations is available from the authors on request. 
The estimates of excess mortality presented in Table 1 are significantly larger than the estimates given by other authors, which, as stated above, is partly the result of their using unsuitable methods for calculating excess mortality over a period of several years. The difference is especially large for the crisis of 1889-1893. Table 1 estimates the number of victims of the Great Famine amounted to approximately 1.3 million people, whereas Urlanis (1963: 83) estimated 500,000 excess deaths just in 1892, and Robbins's estimates (1975: 189) were only 407,000. (Robbins, however, limited his estimate to the 16 worst affected provinces). Obviously a significant part of the discrepancy between this new estimate and older ones is that this new one refers to the five year period of enhanced mortality rather than just one year.

What is the correlation between excess mortality and food consumption? Figure 1 gives data not just for mortality but also for consumption. It should be noted that the harvest data up to 1892-95 were understated by the Central Statistical Committee. In 1892-95 a reform of the calculation method was implemented which led to an approximate 10 per cent increase in the harvest estimates. However, the old estimates were not recalculated, so that part of the post-1893 apparent leap in food consumption shown in Figure 1 is simply a result of the non-comparability of the harvest figures before and after 1893 . The high mortality in 1872 was connected with the poor harvest in 1871. However, it should be noted that the starvation in 1872 was accompanied by a cholera epidemic, which, according to official reports, caused 113,000 deaths. It would seem the high mortality in 1878 was caused by war (against the Turks) and the typhus epidemic which was spread by troop transfers. The crisis of $1882-1883$ was caused by poor harvests (in 1880 and 1881) and was also accompanied by typhus. The crisis of 1889-1893 was accompanied by a cholera epidemic in 1892 (Vasilyev and Segal 1960: 267 and 321).

According to official data, the number of deaths from cholera in 1892 in the 50 provinces of European Russia was 162,000. That number was a relatively small proportion of excess deaths during the crisis. There exist data per province which enable us to analyze the connection between starvation and the spread of cholera. In order to estimate excess mortality in the single year 1892, it is appropriate to take the nearest earlier normal year which is 1888 and the equally distant later year which is 1896. The resulting estimates are presented in Table 2. 
Table 2

Excess mortality and cholera deaths in $\mathbf{1 8 9 2}$

\begin{tabular}{|c|c|c|c|}
\hline Province & $\begin{array}{l}\text { Cholera } \\
\text { mortality }\end{array}$ & Excess deaths & $\begin{array}{c}\text { Other excess } \\
\text { deaths }\end{array}$ \\
\hline Arkhangelsk & 0 & 677 & 677 \\
\hline Astrakhan & 12377 & 21750 & 9373 \\
\hline Bessarabia & 1826 & 17818 & 15992 \\
\hline Chernigov & 540 & 5270 & 4730 \\
\hline Courland & 14 & 0 & 0 \\
\hline Don Host & 18333 & 52080 & 33747 \\
\hline Ekaterinoslav & 2211 & 15309 & 13098 \\
\hline Estonia & 0 & 0 & 0 \\
\hline Grodno & 46 & 2643 & 2597 \\
\hline Kaluga & 35 & 2997 & 2962 \\
\hline Kaunas & 15 & 6134 & 6119 \\
\hline Kazan & 5225 & 31484 & 26259 \\
\hline Kharkiv & 2746 & 14348 & 11602 \\
\hline Kherson & 2717 & 9238 & 6521 \\
\hline Kostroma & 212 & 2654 & 2442 \\
\hline Kursk & 4414 & 18576 & 14162 \\
\hline Kyiv & 5910 & 18313 & 12403 \\
\hline Livonia & 133 & 0 & 0 \\
\hline Minsk & 116 & 248 & 132 \\
\hline Mogilev & 115 & 1012 & 897 \\
\hline Moscow & 872 & 4394 & 3522 \\
\hline Nizhny Novgorod & 1917 & 6142 & 4225 \\
\hline Novgorod & 12 & 1547 & 1535 \\
\hline Olonets & 54 & 1895 & 1841 \\
\hline Orenburg & 6547 & 27528 & 20981 \\
\hline Orlov & 818 & 16317 & 15499 \\
\hline Penza & 3751 & 21718 & 17967 \\
\hline Perm & 2275 & 16325 & 14050 \\
\hline Podolia & 2825 & 15945 & 13120 \\
\hline Poltava & 1059 & 10998 & 9939 \\
\hline Pskov & 39 & 705 & 666 \\
\hline Ryazan & 982 & 16937 & 15955 \\
\hline St. Petersburg & 1799 & 0 & 0 \\
\hline Samara & 18115 & 69835 & 51720 \\
\hline Saratov & 20788 & 56122 & 35334 \\
\hline Simbirsk & 8190 & 24802 & 16612 \\
\hline Smolensk & 4 & 3183 & 3179 \\
\hline Tambov & 9078 & 35296 & 26218 \\
\hline Taurida & 1905 & 7946 & 6041 \\
\hline Tula & 371 & 15153 & 14782 \\
\hline Tver & 18 & 1207 & 1189 \\
\hline
\end{tabular}


Table 2 (continued)

\begin{tabular}{|l|l|l|l|}
\hline \multicolumn{1}{|c|}{ Province } & $\begin{array}{c}\text { Cholera } \\
\text { mortality }\end{array}$ & Excess deaths & $\begin{array}{c}\text { Other excess } \\
\text { deaths }\end{array}$ \\
\hline Ufa & 4531 & 32211 & 27680 \\
\hline Vilna & 5 & 6284 & 6279 \\
\hline Vitebsk & 2 & 0 & 0 \\
\hline Vladimir & 165 & 4347 & 4182 \\
\hline Vologda & 4 & 7767 & 7763 \\
\hline Volhynia & 602 & 1612 & 1000 \\
\hline Voronezh & 12434 & 52288 & 39854 \\
\hline Vyatka & 4981 & 18372 & 13391 \\
\hline Yaroslavl & 548 & 0 & 0 \\
\hline Total & $\mathbf{1 6 1 6 8 6}$ & $\mathbf{6 9 7 4 2 5}$ & $\mathbf{5 3 8 2 3 5}$ \\
\hline
\end{tabular}

Source: Statistics of the Russian Empire (1890-1909), Report on the State of Public Health (1896: 33-134).

Deducting cholera deaths from total excess deaths gives 'other excess deaths', which were caused by the bad harvest and famine. The correlation coefficient between cholera deaths and other excess mortality is 0.84 , which indicates a close relationship between famine and the spread of cholera. Obviously starvation facilitated the spread of cholera. Note that the initial hotbed of the epidemic in European Russia was Astrakhan province to which cholera was brought from Iran. In this province there was a special situation, and if we exclude it from the calculation, the correlation coefficient increases to 0.874 . Hence the intensity of the famine in various provinces accounts for three quarters $\left(\mathrm{r}^{2}=0.76\right)$ of the variation in the spread of cholera.

\section{LATER DEVELOPMENTS}

After the Great Famine the mortality peaks declined. For example, the mortality peak in 1898 only caused 215,000 excess deaths, and that of the two years 1901-1902 only caused 366,000 excess deaths. Comparing the lines for mortality and consumption in Figure 1, it is clear that low levels of consumption caused considerable excess mortality up to and including the crisis of 1901-1902, but after that poor harvests no longer led to big increases in mortality. The mortality peak in 1905 was related to war and revolution, and the 1910 mortality peak to the cholera epidemic (Isupov 2000: 43; Vasilyev and Segal 1960: 275).

Why did the poor harvests of 1906 and 1911 not lead to mass deaths? After the catastrophe of 1892 an effective system of food security was created. The local granaries with supplies held for emergency were strengthened at first by regional and then by national food 
stocks. An important addition to this state system was the aid from various NGOs (Kornilov 2011).

However, starvation did not disappear. What did disappear was the former mass mortality from starvation. Help was only given to those peasants whose family had for a year less than 12 poods per adult and 6 poods per child, an average of 9.6 poods per person. Normal nutrition required 16 poods per person, which means that assistance was only granted to the extremely poor - all the others with insufficient food were left in hunger. Using the harvest statistics, Pavel N. Pershin calculated the number of peasants getting less than 6 poods per head from their land in bad harvest years, that is, aware that they were doomed to starvation. In 1891 there were 19.2 million of them, in $1898-8.0$ million, in $1901-5.6$ million, in $1905-7.1$ million, in 1906 - 16.2 million, in 1911 - 14.9 million. In 1911, the assistance was given to no more than 9 million peasants. The remainder, in order to avoid starvation death had to sell their assets, including livestock (Pershin 1966: 46-48; Nefedov 2010: 38; and Otchet 1913: 76).

The reduction in starvation mortality was a result of the creation of an improved system of food security and is not evidence of growing consumption. Similarly, the long-run decline in mortality, clearly visible in Figure 1, was also not a result of an increase in consumption. It was caused by a reduction in epidemic mortality, resulting from medical and hygienic improvements. After the Great Famine, consumption fluctuated and did not show any clear growing trend. The height of army conscripts, which is a comprehensive indicator of living conditions, had a slight downward trend (Nefedov 2010; Nefedov and Ellman 2016: 161-162).

\section{GEOGRAPHICAL DISTRIBUTION OF EXCESS MORTALITY}

In addition to data about the distribution of excess mortality by time periods, Table 1 also provides data about its spatial distribution. The column 'Total as percent of population in 1897' sums up excess mortality for each province, divided by the population enumerated in the census of 1897 . This enables comparable data on excess mortality for each province to be calculated, which makes it possible to pick out depressed regions. Taking 6 per cent as the threshold, high excess mortality can be found in the provinces of Voronezh, Penza, Ryazan, Simbirsk, Saratov, Samara, Tambov, Kharkiv, and the Don Host. This region (with the exception of the Don Host) was referred to in official documents as an 'impoverished' region. It was known in particular for its tax debts, which were a result of the ruin of many peasants and their sale of property in times of hunger (Shvanebakh 1903). 
On the other hand, there was a region with low excess mortality. This was the Baltic area (Estonia, Courland, and Livonia), Lithuania, Belorussia, and the north-west Russian regions. Not all the provinces in this area were safe with respect to food, but it is worth noting that they differed from the more easterly provinces by having a lower level of mortality. For example, in Minsk province, the level of mortality in 1911-1913 was 2.3 times lower than in Perm province, despite the fact that the level of food consumption in Perm province was higher than that in Minsk province. This was a result of implementing sanitary measures and the general reduction in epidemic mortality, which spread in Russia from West to East (Nefedov 2009).

\section{THE POPULATION MISSING FROM THE CENSUS OF 1897}

Note that, because of the underestimation of mortality in the contemporary official statistics, the figures presented in Table 1 give a low estimate of excess mortality, and that this underestimate is especially important for the crisis of 1889-1893. In this respect the situation of the great famine of 1889-1893 is analogous to the Soviet famine of 19311933. In the latter case excess mortality in the European part of the country, determined on the basis of official death registration statistics, is estimated at 2.9 million. However, if one trusts the official data on mortality and births for the period between 1926 and 1937, and, starting from the census of 1926 , calculates the population that should be alive in 1937, then the estimate for 1937 turns out to be 6.3 million bigger than the population actually registered by the census of 1937 . Some authors consider that a significant part of these 6.3 million was unregistered deaths in the period of the 1931-33 famine (Davies and Wheatcroft 2004: 412-415). (Davies and Wheatcroft themselves estimated that of the 6.3 million discrepancy, 1.1 million was accounted for by unregistered deaths during the famine of 1930-33. However, they stress that this is not a precise figure but a guesstimate, and refer also to authors whose estimate is much larger.) If one applies the same logic, then, starting from the officially registered population in 1885 and calculating the expected population of the 50 provinces in 1897, it turns out that this is 3 million more than the number registered in the census of 1897 (see Table 3). 
Table 3

The 1897 census and the earlier population registration data for the 50 provinces of European Russia

\begin{tabular}{|l|l|l|l|l|l|}
\hline Year & $\begin{array}{c}\text { Population } \\
\text { beginning } \\
\text { of year }\end{array}$ & Deaths & Births & $\begin{array}{c}\text { Natural } \\
\text { increase }\end{array}$ & $\begin{array}{c}\text { Popula- } \\
\text { tion / end } \\
\text { of year }\end{array}$ \\
\hline 1885 & 81725185 & 2883108 & 3957528 & 1124420 & 82849605 \\
\hline 1886 & 82849605 & 2661898 & 3972797 & 1310899 & 84160504 \\
\hline 1887 & 84160504 & 2757722 & 4061523 & 1303801 & 85464305 \\
\hline 1888 & 85464305 & 2760971 & 4268601 & 1507630 & 86971935 \\
\hline 1889 & 86971935 & 2991608 & 4232577 & 1240969 & 88212904 \\
\hline 1890 & 88212904 & 3130996 & 4227915 & 1096919 & 89309823 \\
\hline 1891 & 89309823 & 3095552 & 4372419 & 1276867 & 90586690 \\
\hline 1892 & 90586690 & 3596585 & 4033402 & 436817 & 91023507 \\
\hline 1893 & 91023507 & 3028300 & 4298323 & 1270023 & 92293530 \\
\hline 1894 & 92293530 & 3062022 & 4391658 & 1329636 & 93623166 \\
\hline 1895 & 93623166 & 3213841 & 4539176 & 1325335 & 94948501 \\
\hline 1896 & 94948501 & 3063047 & 4634809 & 1571762 & 96520263 \\
\hline $\mathbf{1 8 9 7}$ census & $\mathbf{9 3 4 4 2 8 6 4}$ & & & & \\
\hline Discrepancy $^{\mathbf{a}}$ & $\mathbf{3 0 7 7 3 9 9}$ & & & & \\
\hline
\end{tabular}

Note: a) This is the difference between the estimated population at the end of 1896 and the population enumerated by the census in January 1897.

Source: Contemporary official statistics (see the sources to Tables 1 and 2).

What explains this discrepancy? Part of it could result from underestimation of the population by the census. Underestimation of difficult-to-reach people is common in censuses, and the 1897 census was the first census in the Russian Empire, carried out in mid-winter, in a country with a population scattered over large rural areas and with poor communications. Part could be internal migration or emigration. Nevertheless, part of it, as in 1937, could be the result of mortality under-registration during the preceding famine. Perhaps, it is necessary to add part of it to the famine mortality. Further research is necessary to clarify this matter.

\section{THE CAUSE OF THE FAMINE}

The catastrophe of 1889-93 had much in common with the catastrophe of 1931-1933. Both catastrophes were provoked by the state's attempts to take grain from the peasants to ensure industrialization. In the late nineteenth century, Russian industrialization lagged a long way behind that in Europe (and the USA). However, the attempts to improve this situation were hindered by the fact that Russia in the 1880s experienced budget deficits, current account deficits, and a de- 
clining exchange rate. This led to difficulties in borrowing and refinancing maturing debts. The interest rates on government bonds were substantially higher than those in the major European countries. For example, in 1885, in St Petersburg the yield on government bonds was 5.6 per cent, whereas in Berlin it was 4.14 per cent and in Paris 3.0 per cent (Khadonov 1997: 72). It also discouraged foreign capital, which was put off by exchange-rate risk. To drive down the interest rate on government debt, make refinancing easier, and attract foreign capital, it was necessary to stabilize the exchange rate, which required a positive balance on the current account of the balance of payments leading to an accumulation of gold reserves. The end result would be to go on the gold standard (this eventually happened in 1897). This was expected to reduce the government's financial difficulties (by reducing interest rates on its debts) and make Russia attractive for foreign capital, both of which would assist Russia's industrialization plans. The Ministry of Finance (responsible not only for finance but also for economic development) was ambitious to promote industrialization, in particular railway-building. Since grain was Russia's main export item, the achievement of these plans required large and stable grain exports. In 1884-1885 the then Finance Minister Nikolai Bunge undertook an inspection tour, examined all the ports of European Russia, and announced a programme of measures for increasing grain exports. From 1885 loans were granted on the security of grain for export. In 1889 , in order to stimulate grain exports, the new Minister of Finance Ivan Vyshnegradsky (appointed in 1887) implemented a radical reduction of railway freight charges and introduced export bounties (Stepanov 1998: 166). However, these measures themselves were inadequate.

... in order to increase exports, the peasants had to be compelled to place more grain on the market even at the expense of their own consumption. An intensive economic pressure would be needed to accomplish this goal.

Vyshnegradsky applied the required pressure vigorously. During his first half-year in office, the new Minister of Finance took steps which raised the prices of many items of peasant consumption. Taxes on spirits were increased, and those on tobacco were raised by as much as 100 per cent in some cases. State revenues from the land tax grew by 3 million roubles. The government imposed heavier duties on a number of imports, including iron and steel implements used by peasant agriculturalists. The apogee of this aspect of Vyshnegradsky's policy came in the very year of the 
famine when Russia adopted a new tariff, making her imposts among the highest in the world. The Minister of Finance also urged tax inspectors to redouble their efforts in obtaining arrears due on the 'soul tax', despite the fact that the tax itself had been abolished in 1886 (Robbins 1975: 7).

The methods used to collect taxes were very severe. Defaulters could have their property sold (which happened to a hundred thousand households in 1895-96). Volost (a unit of administrative division) and village elders, and also tax collectors, were often arrested if they were unable to squeeze out the taxes and debts due from the peasants. As Wheatcroft (191: 169-170) observed:

Faced with these kinds of pressure the local authorities and tax collectors naturally turned to brutality in order to save themselves from arrest and punishment. The system was notoriously harsh, and it was only by means of such repressive measures, backed up by the strength of the police and the army, that the taxes were collected and the debts kept within order.

Simultaneously with these efforts to increase tax payments, paying them became more difficult as a result of a decline in grain prices. In the Central Black-Earth region the average price of rye fell from 72 kopeks a pood in 1881-1885 to 45 kopeks in 1886-1890, which meant that paying taxes required selling 1.6 times as much grain. Petr Shvanebakh calculated that, if a peasant retained for own consumption 13 poods per head, and sold the remaining grain, then in 1883-1887 payment of direct taxes would require 62 per cent of the sale proceeds in Voronezh province, 50 per cent in Saratov province, 58 per cent in Tambov province, and 70 per cent in Kursk province. In Penza, Ryazan and Tula provinces, the entire sum from grain sales would be inadequate to pay taxes (Shvanebakh 1903: 12, 162-166; Anfimov 1984: 90).

Squeezing the pips out of the peasantry led to an increase in exports per head of the population by a half: from 3.9 poods in $1884 / 85$ $1886 / 87$ to 5.8 poods in $1887 / 88-1889 / 90$. As a result of the influx of gold and foreign exchange, the exchange rate of the paper rouble against the gold rouble rose from 65 kopeks to 80 kopeks. The government was able to print paper roubles and exchange them for gold, making possible the introduction in due course of the gold standard (and also avoiding the deflation that a rising currency would cause). (Witte 1960: 219-221. For annual exchange rates of the gold rouble against the paper rouble in the pre-gold standard period, see Owen 1980: 705). This increase in grain exports per head was a conscious 
policy to facilitate industrialization at the expense of a temporary reduction in bread consumption within the country.

In 1889 there was a bad harvest. According to official statistics the net harvest per person was only 15.9 poods. Prices rose, but thanks to the reduction in transport costs, exports remained profitable. Exports amounted to 4.9 poods per head, and as a result the quantity remaining for consumption fell to an unprecedentedly low level. In several provinces starvation began and mortality rose sharply, but there was not a catastrophe because in the preceding years there had been good harvests and households had built up stocks. In the following year the harvest was mediocre, less than average, but exports remained high. The grain remaining for domestic consumption was again below the normal level, and people once again relied on stocks. 'The foreign trade policy of Vyshnegradsky was not for nothing termed "hunger by export" ... In a number of regions no significant grain stocks remained, so that another bad harvest was bound to lead to mass starvation' (Stepanov 1998: 110, 166). The exhaustion of stocks is evident also in information from particular provinces. According to the report of the Voronezh district police officer (Kniga 1997: 60): 'Although in 1890 the harvest was not so bad, it was not adequate to meet all requirements, to create the necessary stocks ... The poor harvest in the current year ... given the complete absence of fodder and food reserves, placed the majority of the peasant households in a hopeless situation.'

When, in the spring of 1891, information from the regions about the approaching crop failure began to arrive, the agronomist and Director of the Department for Uncollected Taxes Alexey S. Ermolov sent a memo to Vyshnegradsky in which he wrote about 'terrible signs of famine' (Ermolov 1909: 100). However, the Minister of Finance ignored this warning and the export of grain continued during the summer. It was only in mid-August that the export of rye (the main food for the peasants) was banned. (On 28 July 1991 the government announced a ban on the export of rye. However, it was not to be implemented immediately, in order to allow merchants to fulfil their contracts with foreign buyers, and to enable the Ministry of Finance to minimize the harm to its economic programme. The interval between the announcement of the ban and its implementation naturally led to a big increase in rye exports in the three weeks in which this was still permitted.) In October-November the ban was extended to other grains. 'We ourselves won't eat, but we will export!' stated Vyshnegradsky (Shvanebakh 1901: 21). 
Because of the bad harvest the net grain yield per person was about 14 poods, stocks were exhausted by the exports in the previous years, and as a result there was a dreadful famine. Since many starving families did not have enough grain for seed, in some provinces 1892/93 was also a year of crop failure and high mortality. The crisis only ended with the abundant harvest of 1893.

It is interesting to compare the arguments presented in the present paper with the evaluations made by a number of well-known specialists. 'The tragedy was provoked by the fiscal policy of Vyshnegradsky, which was notable for its great cruelty' (Ananyich and Ganelin 2000: 58) 'Pre-revolutionary historians and economists gave Vyshnegradsky a severe sentence. The Minister of Finance was accused of the imprudent export of grain, which aggravated the famine of 189192 ...' (Stepanov 1998: 239) 'In the wake of the famine of 1891, many critics would blame the disaster on Vyshnegradsky... In our own day, too, scholars have accused the Tsar's government of sucking the country dry and have compared the causes of the crisis of 1891 with those of the tragic events of 1932-1933' (Robbins 1975: 8).

The present authors agree with this comparison. We have argued elsewhere (Nefedov and Ellman 2019) that the cause of the 1931-34 famine was the conflict between the state and the peasants (and Kazakh herders) over the distribution of grain (and meat) production between the subsistence needs of the rural population and the industrialization policies of the state. Detailed similarities between the two famines are first: hostility to the so-called kulaks and blaming them for many of the difficulties. (The term 'kulak', and the idea that they were exploiting the mass of the peasants, were commonplace in official correspondence and statements by officials in 1891-92 and were not an invention of the Bolsheviks.) Secondly, concentrating relief on seed and food (for people) in that order and neglecting livestock (although in 1891-92 the Tsarist authorities did provide a substantial number of horses to replace those that had died as a result of inadequate fodder). Thirdly, giving relief in the form of loans not grants. Fourthly, export of grain during the crisis (about such policy in 189192, see, for example, Rock 2015). One important difference between the two famines is the effort the state made in the 1930s to solve the grain problem by a technological breakthrough - the use of tractors and combine harvesters.

\section{CONCLUSION}

This paper has presented an estimate of the number of victims of the famine that peaked in 1892 which is much higher than the previously 
presented estimates. This is because the present paper does not make the largely artificial distinction between cholera epidemics and famine deaths and estimates excess deaths for the whole famine period and not for just one year (we choose different years as the normal years for comparison); and, in its comparison of the famine years with normal years, takes account of the fact that the population was growing in this period (making geometric averages more appropriate than arithmetic averages to calculate excess mortality). The paper also suggests that some part of the 3 million people missing from the 1897 census may also have been victims of the famine, which would increase the number of excess deaths even more. This conclusion has implications for two issues that have generated a large historical literature. They are the development of the economy and living standards in the Russian Empire between the emancipation of the serfs and the revolution of 1917; and the interpretation of the Soviet famine of 1931-34 (with its peak in 1933).

In the historical literature, the traditional pessimistic view of the development of living standards in the last decades of the Russian Empire has been largely replaced by an optimistic view. However, the optimistic view requires, at a minimum, some nuance in the light of the data presented in this paper. First, the scale of the famine which peaked in 1892 is greater than previously assumed, which lends support to the pessimistic view. Secondly, up to and including the crisis of 1901-1902 a large part of the peasantry - i.e. the overwhelming majority of the population - lived near the subsistence minimum and was regularly vulnerable to starvation as a result of bad harvests. Thirdly, the population growth without increasing average food consumption means that the absolute number of peasants in poverty must have been increasing. Fourthly, the infant and child mortality rates remained high while life expectancy at birth was correspondingly low. Fifthly, there were 'high levels of income inequality even within rural societies' (Dennison and Nafziger 2013: 440). Sixthly, the large geographical differences in the Empire make generalizations about the whole Empire inappropriate. In addition, the pessimistic view had wide support among public opinion at the time, as Adamets (2002: 158) observed:

At the beginning of the twentieth century, when Russia accounted for about one-quarter of global cereal production, the sense that famines were becoming more serious within the country's borders was gaining wide currency among the public. Peasant impoverishment and famine were at the cen- 
tre of debates in the Duma from its first sessions in 1906, and they influenced the passage of important institutional and economic reforms that affected rural society.

However, there is some consolation for the optimists. The longrun increase in population required rising land productivity (and an increase in the sown area, often with negative environmental consequences). In his monograph on Russian grain production, Ostrovsky (2013: 216) pointed out that, "progress in grain production in the half century following emancipation of the serfs definitely took place, but was less than it would seem [from the official statistics on grain yields]'. The situation in the Baltic area, Lithuania and Belorussia was relatively good. There was a long-run downward trend in mortality, which is especially notable from about 1883 onwards. This trend probably resulted mainly from the spread of improved hygiene from Europe. There was also a long-run upward trend in literacy, although with a big gender gap (Brooks 1985; Eklof 1986). Industrialization, and with it GDP, made significant progress (Gregory 1982).

Andrei Markevich and Ekaterina Zhuravskaya (2018) have recently presented an important article supporting the optimistic interpretation. Their work is marked by prolonged and detailed research and methodological sophistication. However, some of its conclusions are undermined by two problems. First, its conclusion about the increase in nutrition of peasants from former serf estates in the post-Emancipation period is based on data on average height for adults. Nefedov and Ellman (2016: 162), however, showed that there was no increase in the average height of the army recruits born between 1851-55 and 1886-90 (on the contrary, there was observed a slight fall). Hence, for that period, the data on average height for males and females are not evidence of an increase in average peasant nutrition. Secondly, in the aforementioned article the conclusion about the increase in agricultural production is based on the official statistics. However, the authors ignore the long debate on the accuracy of the statistics and whether they should be corrected (Wheatcroft and Davies 1984: 108; Ostrovsky 2013: 196-201 and 216). Official statistics do show a substantial growth of the gross output of grain in the half century following Emancipation. However, part of this apparent growth was the result of the 1892-95 change in the statistical methods used for estimating the gross output (Ostrovsky 2013: 216). Part resulted from the expansion of the sown area. Moreover, in the two decades from 1896 to 1915 there were fluctuations in average net output per inhabitant but no significant increasing trend (and in the Centre and North there was even observed a de- 
clining one [Ostrovsky 2013: 224]). However, it does seem to be true, and this supports Markevich and Zhuravskaya's argument about the effects of the abolition of serfdom, that the growth rate of productivity in grain production in the post-Emancipation period was higher than in the pre-Emancipation period. In the first half of the nineteenth century it seems that the rye yield-seed ratio in the Voshchazhnikov estate in Yaroslavl province (Dennison 2011: 35) was no higher than in Central Russia in the second half of the eighteenth century (Kahan 1985: 49).

As far as the interpretation of the 1931-34 famine is concerned, the present paper argues that both the famine which peaked in 1892 and the one which peaked in 1933 had the same main cause. In both cases the main cause was the state's desire to take part of the grain output in order to use it to facilitate industrialization. (In 1931-34, the peasants' resistance to grain procurements and the state's response to it played a more significant role.) Hence this paper supports Devereux's (1993) explanation of famines in political economy terms (although it rejects for the 1931-34 case Devereux's exclusive attention to the Ukrainian victims at the expense of the Kazakh and Russian victims, and also rejects the genocide interpretation). It also supports the argument of Davies and Wheatcroft (2004: 434) that: 'The fundamental cause of the deterioration of agriculture in 1928-33 was the unremitting state pressure on rural resources.' Furthermore, if the excess deaths from both famines are limited to European part of the country (i.e., the famine in Kazakhstan is omitted), the famine victims are calculated as a proportion of the population rather than in absolute numbers, and part of the 3 million people missing from the census of 1897 are considered to be famine victims, then the two famines would be comparable in scale as well. This would place Stalin in the tradition of Vyshnegradsky and suggest that he was not a unique mass murderer but rather a continuer of the imperial Russian industrialization strategy. As befits a revolutionary, he implemented that strategy in a more radical way. He used more violence, provided less relief during the crisis, and sought the solution in a technological breakthrough.

\section{REFERENCES}

Adamets, S. 2002. Famine in Nineteenth- and Twentieth-Century Russia: Mortality by Age, Cause, and Gender. In Dyson, T., and Ó Grada, C. (eds.), Famine Demography (pp. 158-180). Oxford: Oxford University Press.

Ananyich, B. V., and Ganelin, R. Sh. 2000. Sergei Yulievich Witte and his Time. St. Petersburg: Dmitrii Bulanin. Original in Russian (Ананьич Б. В., 
Ганелин Р. Ш. Сергей Юльевич Витте и его время. СПб: «Дмитрий Буланин»).

Anfimov, A. N. 1984. Economic Situation and the Class Struggle of the Peasants of the European Russia. 1881-1904. Moscow: Nauka. Original in Russian (Анфимов А. М. Экономическое положение и классовая борьба крестьян Европейской России. 1881-1904 г2. М.: Наука).

Baten, J., and Wagner, A. 2002. Autarchy, Market Disintegration, and Health: The Mortality and Nutritional Crisis in Nazi Germany, 1933-1937. Economics and Human Biology 1 (1): 1-28.

Brooks, J. 1985. When Russia Learned to Read: Literacy and Popular Literature, 1861-1917. Princeton: Princeton University Press.

Davies, R., and Wheatcroft, S. 2004. The Years of Hunger: Soviet Agriculture, 1931-1933. Basingstoke: Palgrave Macmillan.

Dennison, T. 2011. The Institutional Framework of Russian Serfdom. Cambridge: Cambridge University Press.

Dennison, T., and Nafziger, S. 2013. Living Standards in Nineteenth-Century Russia. The Journal of Interdisciplinary History 42 (3): 397-441.

Devereux, S. 1993. Theories of Famine. New York: Harvester Wheatsheaf.

Eklof. B. 1986. Russian Peasant Schools: Officialdom, Village Culture, and Popular Pedagogy, 1861-1914. Berkeley: University of California Press.

Ermolov, A. S. 1909. Our Harvests and the Food Problem. Part 1. St. Petersburg, Original in Russian (Ермолов А. С. Наши неурожаи и продовольственный вопрос. Ч. І. СПб.).

Gregory, P. 1982. Russian National Income, 1885-1913. Cambridge: Cambridge University Press.

Isupov, V. A. 2000. Demographic Catastrophes and Crises in Russia in the First Half of the $20^{\text {th }}$ Century. Novosibirsk: Sibirskii khronograf. Original in Russian (Исупов В. А. Демографические катастрофы и кризисы в России в первой половине XX века. Новосибирск: Сибирский хронограф).

Kahan, A. 1985. The Plow, the Hammer and the Knout: An Economic History of Eighteenth Century Russia. Chicago: Chicago University Press.

Khadonov, E. E. 1997. Essays from the History of the Financial and Economic Policy of Post-Reform Russia (1861-1904). Moscow: YUPAPS. Original in Russian (Хадонов Е. Е. Очерки из истории финансово-экономической политики пореформенной России (1861-1904 г2.). М.: ЮПАПС).

Kniga, M. D. 1997. History of the Famine of 1891-1892 in Russia (Ph.D). Voronezh. Original in Russian (Книга М. Д. История голода 18911892 г2. в России. Дисс... к. и. н. Воронеж).

Kornilov, G. E. 2011. Formation of the Food Safety System of the Russian Population in the First Half of the $20^{\text {th }}$ Century. Rossiiskaya istoriya 3: 91-101. Original in Russian (Корнилов Г. Е. Формирование системы 
продовольственной безопасности населения России в первой половине XX в. Российская история 3: 91-101).

Markevich, A., and Zhuravskaya, E. 2018. The Economic Effects of the abolition of Serfdom: Evidence from the Russian Empire. American Economic Review 108 (4-5): 1074-1117.

Mokyr, J., and Ó Grada, C. 2002. Famine Disease and Famine Mortality: Lessons from the Irish Experience, 1845-50. In Dyson, T., and Ó Grada, C. (eds.), Famine Demography (pp. 19-43). Oxford: Oxford University Press.

Nefedov, S. A. 2005 Demographic and Structural Analysis of the SocioEconomic History of Russia. Ekaterinburg: Izd. UGGU. Original in Russian (Нефедов С. А. Демографически-структурный анализ сочиально-экономической истории России. Екатеринбург: Изд. УГГУ).

Nefedov, S. A. 2009. About the Connection of Demographic Indicators and Consumption in Russia at the end of the $19^{\text {th }}$ - beginning of the $20^{\text {th }}$ centuries. Rossiiskaya istoriya 2: 155-162. Original in Russian (Нефедов С. А. О связи демографических показателей и потребления в России конца XIX - начала XX века. Российская история 2: 155-162).

Nefedov, S. A. 2010. About the causes of the Russian revolution. In Grinin, L. E. et al. (eds.), About the Causes of the Russian Revolution (pp. 2560). Moscow: URSS. Original in Russian (Нефедов С. А. О причинах русской революции. О причинах русской револющии / ред. Л. Е. Гринин и др., с. 25-55. M.: URSS).

Nefedov, S. A., and Ellman, M. 2016. The Development of Living Standards in Russia before the First World War: An Examination of the Anthropometric data. Revolutionary Russia 2: 149-168.

Nefedov, S., and Ellman, M. 2019. The Soviet famine of 1931-34: Genocide, a Result of Poor Harvests, or the Outcome of a Conflict between the State and the Peasants? Europe-Asia Studies 71 (5): 1048-1065.

Ostrovsky, A. V. 2013. Grain Production in Russia in the late $19^{\text {th }}$ - early $20^{\text {th }}$ Century. St. Petersburg: Poltorak. Original in Russian (Островский, А. В. Зерновое производство России в конще XIX - начале XX вв. СПб.: Ролторак).

Report on the state of public health and the organization of medical care in Russia for 1892. St.Petersburg: MVD, 1896. Original in Russian (Oтчет о состоянии народного здравия и организации врачебной помощии в России за 1892 год. Санкт-Петербург: Издание МВД).

Report on the food campaign of 1911-1912. Vol. 1. 1913. St. Petersburg: MVD. Original in Russian (Отчет по продовольственной кампании 1911-1912 г2. Т. 1. СПб.: Тип. МВД).

Owen, T. 1989. A Standard Ruble of Account for Russian Business History, 1769-1914: A Note. The Journal of Economic History 49 (3): 699-706. 
Pankratov, A. S. 1913. Without Bread. Essays on the People's Disaster. Moscow: Portugalov. Original in Russian (Панкратов А. С. Без хлеба. Очерки народного бедствия. М.: Издание В. П. Португалова).

Pershin, P. N. 1966. Agrarian Revolution in Russia. Book 1. From reform to revolution. Book 1. Moscow: Nauka. Original in Russian (Першин П. Н. Аграрная революиия в России. Кн. 1).

Prentice, A. et al. 2008. New Challenges in Studying Nutrition-Disease Interactions in the Developing World. The Journal of Clinical Investigation 118 (4): 1322-1329.

Rashin, A. G. 1956. Population of Russia for 100 years. Moscow: Gosstatizdat. Original in Russian (Рашин А. Г. Население России за 100 лет. M.: Госстатиздат).

Robbins, R. 1975. Famine in Russia, 1891-1892. New York: Columbia University Press.

Rock, B. 2015. A Province in Crisis: The Russian Famine of 1891-92 in Tambov Province. $\mathrm{PhD}$ thesis, University College London. URL: www.ucl.ac.uk. Accessed October 6, 2019.

Collection of Information on Russia for 1884-1885. 1887. St. Petersburg: MVD. Original in Russian (Сборник сведений по России за 1884-1885. СП,.: Вздательство МВД, 1887).

Shvanebakh, P. Kh. 1901. Money Circulation and the National Economy. St. Petersburg: Stasyulevich. Original in Russian (Шванебах П. Х. Денежное обращение и народное хозяйство. СПб.).

Shvanebakh, P. Kh. 1903. Our Tax Service. St. Petersburg: Stasyulevich. Original in Russian (Шванебах П. Х. Наме податное дело. СПб.).

Shverin, T. 1901. The Role of Starvation in the Development of an Epidemic. Meditsinskaya beseda 1: 254-263. Original in Russian (Шверин Т. Роль голодания в развитии эпидемии. Медииинская беседа 1: 254-263).

Statistics of the Russian Empire. Vols. 12, 16, 18, 21, 24, 33, 34, 38, 45, 47, 48, 50, 67, 70 1890-1909. St.Petersburg: Izd.TsSK. MVD. Original in Russian (Статистика Российской империи. Т. 12, 16, 18, 21, 24, 33, 34, 38, 45, 47, 48, 50, 67, 70. СПб: Издательство ЦСК МВД).

Statistical bulletin of the Russian Empire. Seriya II, vyp. 12-14, 17, 18, 2025. Seriya III vyp. 3, 7, 8, 20, 21, 23, 24. 1877-1887. St. Petersburg, MVD. Original in Russian (Статистический временник Российской империи. Серия II. Вып. 12-14, 17, 18, 20-25. Сер. III. Вып. 3, 7, 8, 20, 21, 23, 24. СПб: Издательство МВД).

Statistical Yearbook of Russia. 1904-1915. St. Petersburg 1905-1916: Izd. TsSK MVD. Original in Russian (Статистический ежегодник России. 1904-1915. СПБ: Издательство ЦСК МВД).

Stepanov, V. L. 1998. Kh. Bunge. The Fate of a Reformer. Moscow: ROSSPEN. Original in Russian (Степанов В. Л. Х. Бунге. Судьба реформатора. М.: Росспэн). 
Urlanis, B. Ts. 1963. Fertility and Life Expectancy in the USSR. Moscow: Gosstatizdat. Original in Russian (Урланис Б. Ц. Рождаемость и продолжительность жизни в СССР. М.: Госстатиздат).

Vasilyev, K. G., and Segal, A. E. 1960. History of Epidemics in Russia. Moscow: Gosudarstvennoe izdatelstvo meditsinskoi literatury. Original in Russian (Васильев К. Г., Сегал А. Е. История эпидемий в России. М.: Государственное издательство медицинской литературы).

Wheatcroft, S. 1991. Crises and the Condition of the Peasantry in Late Imperial Russia. In Kingston-Mann, E., and Mixter, T. (eds.), Peasant Economy, Culture, and Politics of European Russia (pp. 128-172). Princeton: Princeton University Press.

Wheatcroft, S. G. 1992. The 1891-92 famine in Russia (pp. 44-64). In Edmondson, L., and Waldron, P. (eds.), Economy and Society in Russia and the Soviet Union, 1860-1930. New York: St. Martin's Press.

Witte, S. Yu. 1960. Memoirs. Vol. 1. Moscow: Sotsegiz. Original in Russian (Витте С. Ю. Воспоминания. Т. І. М.: Соцэгиз). 